\title{
IMPLEMENTATION OF ONLINE LEARNING PROGRAM IN MIGRANT COMMUNITY: TEACHERS' CHALLENGES AND SUGGESTIONS
}

\author{
Sandar LWIN \\ ORCID: 0000-0002-2951-3569 \\ Faculty of Education \\ Prince of Songkla University \\ Pattani, THAILAND \\ Dr. Ekkarin SUNGTONG \\ ORCID: 0000-0002-0067-9119 \\ Faculty of Education \\ Prince of Songkla University \\ Pattani, THAILAND \\ Dr. Virintorn AUKSORNNIT \\ ORCID ID: 0000-0001-7110-709X \\ Faculty of Education \\ Prince of Songkla University \\ Pattani, THAILAND
}

Received: 08/11/2020 Accepted: 23/06/2021

\begin{abstract}
While several scholarship opportunities are available to Myanmar migrants and refugee students in Thailand, many students face difficulties finding affordable and convenient ways to prepare for university entry requirements. To provide lifelong learning opportunities for these marginalized young adults, flexible online learning programs can play a significant role. This exploratory qualitative case study presents the challenges hindering the implementation of an online learning program in Mae Sot, a Thai town on the border with Myanmar. The study also reports suggestions of the participants in dealing with challenges of online learning for migrant students. Nine administrators and teachers of migrant learning centers (MLCs) in Tak province participated in this study. Semi-structured interviews and document analysis were methods applied. Although the migrant community acknowledges the benefits and opportunities of online learning, MLCs have not yet fully implemented eLearning as a mode of education. There are particular challenges to effectively implement the online learning program in the migrant community. Six challenges are identified: accessibility, support services, attitude, networking, contents, and accreditation, along with solutions proposed by the participants. This study claims that lack of accessibility, attitude and networking in the community are the major barriers among the other challenges in the migrant community. In dealing with challenges, three main recommendations proposed by the participants were: to develop courses for the beginner level, to establish an online learning study center with suitable infrastructure and resources in the migrant community, and to have regular communications with the migrant education providers.
\end{abstract}

Keywords: eLearning, online learning, migrant education, migrant children in Thailand.

\section{INTRODUCTION}

Due to labor shortages, migrant workers from neighboring Myanmar, Cambodia, and Lao PDR make up nearly $10 \%$ of Thailand's labor force (Chamratrithirong \& Punpuing, 2017). The poor economic situation, political insecurity, internal conflicts, oppression of minorities, natural disasters and forced 
relocations have driven Myanmar nationals to flee their homeland as internally displaced persons (IDPs), documented and undocumented migrants or refugees to neighboring Thailand for decades (Alienor Salmon, Thanwai, \& Wongsaengpaiboon, 2013; Thet \& Pholphirul, 2016). More than 3 million cross-border migrants have worked in Thailand has led to an increasing number of migrant children born in the country (Chamratrithirong \& Punpuing, 2017; Global Education Monitoring Report, 2019; Harkins, 2019; International Labour Organization, 2017). As the migrant population has grown, the need for education for those children increased (Dowding, 2014). Several factors such as government schools officially accepting migrant children, and providing certificates of graduation have enabled the increase to around $50 \%$ of the migrant students attending public schools (Harkins, 2019; Nawarat, 2012). However, Myanmar migrant children face numerous challenges to access the Thai public education system such as financial constraints, the parent's legal status, and of course language barriers in curriculum and instruction (Nawarat, 2012, 2018; Petchot, 2014). Additionally, the parents of migrant children can be required to move work locations frequently, have unstable work situations, and may work on rural plantations with no access to education resources. Students are often forced to drop out in the middle of the school year because of their parents' unstable work situation. Migrant students are often caught between the effects of migrant labor policy in Thailand and their pursuit of basic education. Some children drop out in the middle of the school year because of their parents' unstable work situation which requires moving from one place to another from time to time. Therefore, even the children enrolled in Thai public schools barely complete secondary education. Some children thus attend non-formal migrant learning centers. The majority of children stay with their migrant worker parents and gradually enter undocumented employment (Nawarat, 2018).

Individuals, communities, and organizations have acted to respond to the education needs of migrant children. The migrant community established migrant learning centers (MLCs) to provide learning opportunities for the marginalized groups over the past two decades. MLCs provide a range of educational opportunities including basic education from pre-school to post-ten. Additionally, many MLCs include vocational training programs or community development training to serve the migrant and refugee communities and to provide further support to the children who are attending the Thai government schools to help them to follow the lessons (Nawarat, 2012). Some of the MLCs implement online or in-class programs preparing for tertiary education.

The students of MCLs are from various backgrounds. Some are children of migrant workers, others are from the refugee camps, and others yet cross the border into Thailand every day just to attend school (Dowding, 2014). Since 2015, MLCs in Tak have become more organized and interact with each other under the Migrant Education Coordination Center (MECC). These MLCs are partially recognized by the Thai authorities in Tak province, and some are supported by international donors (World Education, 2011).

However, until now, MLCs are not fully recognized as a part of either Myanmar or Thai formal education systems. As a result, vast numbers of students graduate from MLCs with unrecognized diplomas (Arphattananon, 2012; Global Education Monitoring Report, 2019; Help Without Frontiers, 2018; MacLaren, 2013; Nawarat, 2018; Save the Children \& World Education, 2014; UNESCO- News, 2015). Many MLCs want to continue their education at the university level, they want to work with NGOs, and they want to serve their communities. After they complete their informal education in refugee camps or migrant learning centers, they often are unsure about the next step. Many children follow their parents and become migrant workers (Arphattananon, 2012; Dowding, 2014). Several groups of Non-Government Organizations (NGOs) and Community Based Organizations (CBOs) have jointly tried to help these students with the relevant skills they need to pursue their goals. And, while a variety of scholarship opportunities are available to migrants and refugee students; many students do not have recognized diplomas of completing secondary education. Almost every university in the world requires a recognized high school diploma for entrance.

MLCs recognized this need and developed programs to prepare students to take an internationally recognized high school equivalency test, which is the General Education Development (GED) high school equivalency test of the United States (Chongkittavorn, 2012). A couple of international programs offer online education for Myanmar migrants in Thailand such as the UoP- University of People (Itthipongmaetee, 2018) and the ACU-Australian Catholic University (2009). To enter international scholarship programs, English proficiency is essential (Chongkittavorn, 2012). To assist in reaching it, the Exam Preparation Outreach 
Program (EPOP)- the subject of our case study - launched an online learning program (Thabyay Education Foundation, 2017). Online learning programs are regarded as a way to address challenges in the higher education pathway for children of migrants and refugees (Halkic \& Arnold, 2019). The application of online or blended learning can also be seen as one of the approaches to provide non-formal education and adult learning to support disadvantaged students (Halkic \& Arnold, 2019; Jury, Sherer, David, \& Morganti, 2016; MacLaren, 2013).

\section{Review of Related Literature}

The utilization of information and communication technology in education has provided many tools to improve the effectiveness of the teaching and learning processes over recent decades (Hennebury, 2007). eLearning, also known as online learning or distance learning, is the abbreviation of electronic learning through the use of the internet and electronic devices as the medium for teaching and learning. Online learning is a technology-enhanced method that offers an opportunity for the learners to practice at their own pace to develop proficiency and to educate themselves regardless of their geographical location, socioeconomic situation, and/or biographical factors (Brendan, 2008). In the digital age, eLearning is one of the emerging technology-enhanced innovative learning tools in educational practices (Cross, 2004; Rosenberg, 2001, pp. 31-32). The utilization of eLearning is growing rapidly. Online teaching and learning practices have been adopted in various industries. Studies concerning eLearning include its implementation in vocational education and training (Konayuma, 2015), job training (Eidson, 2009), nursing education (Saint-Marc, Ratiney, \& Schlatter, 2019), and medical education (Mirmoghtadaie, Ahmady, Kohan, \& Rakhshani, 2019; Mohebi, Parham, Sharifirad, \& Gharlipour, 2018).

Several interrelated challenges in the implementation of eLearning in developing as well as developed countries have also been identified in the literature. The lack of suitable devices, inadequate skills, attitude, and poor support services, varying levels of experience and knowledge of teachers in eLearning hindered implementation of vocational education and training in Zambia (Konayuma, 2015). In Ghana, high cost, unstable power supply, and course contents were barriers in accessing online learning (Adjabeng, 2017) (Adjabeng, 2017). Rezaei (2009) found cultural, educational, technical, and financial situations triggered challenges in developing online learning in higher education institutions in Iran. Lack of technical infrastructure, design, cyberbullying, lack of support and training, lack of student motivation, and weak engagement with technology-enabled learning were found as the challenges of a Massive Open Online Course (MOOC) in Canada. Andersson (2008) argued that major challenges for e-learning in Sri Lanka were student support, flexibility, teaching and learning activities, access, academic confidence, localization, and attitudes. The review of literature has revealed that very few studies on challenges of implementation of e-learning have been carried out in the context of higher education for migrant children and none in Thailand. Building on these previous studies, this case study explored the challenges of implementing an eLearning program called Exam Preparation Outreach Program (EPOP) within the migrant community in Thailand.

\section{Online Learning for Myanmar Migrant Children in Thailand: Exam Preparation Outreach Program (EPOP)}

The Exam Preparation Outreach Program (EPOP) provides university and test preparation services for individuals who need support to join the higher education pathway and for professional development for their future careers. The contents of EPOP courses are designed for developing university-level academic English skills and exam preparation for the English proficiency paper-based test, TOEFL ITP. EPOP offers Academic English level 1 and level 2 courses which aimed to raise students' English proficiency to a level where they can actively and successfully participate in university courses in English. These courses provide students a foundation in Academic English listening, reading, writing, and critical thinking skills. Content areas include science, history, and social studies. TOEFL Exam Preparation courses are the next level after a student has completed the Academic English courses. TOEFL courses prepare students specifically for the TOEFL ITP exam. The exam preparation courses are designed for students at an upper-intermediate level of English who are ready to begin applying for international university programs (Thabyay Education Foundation, 2017). 


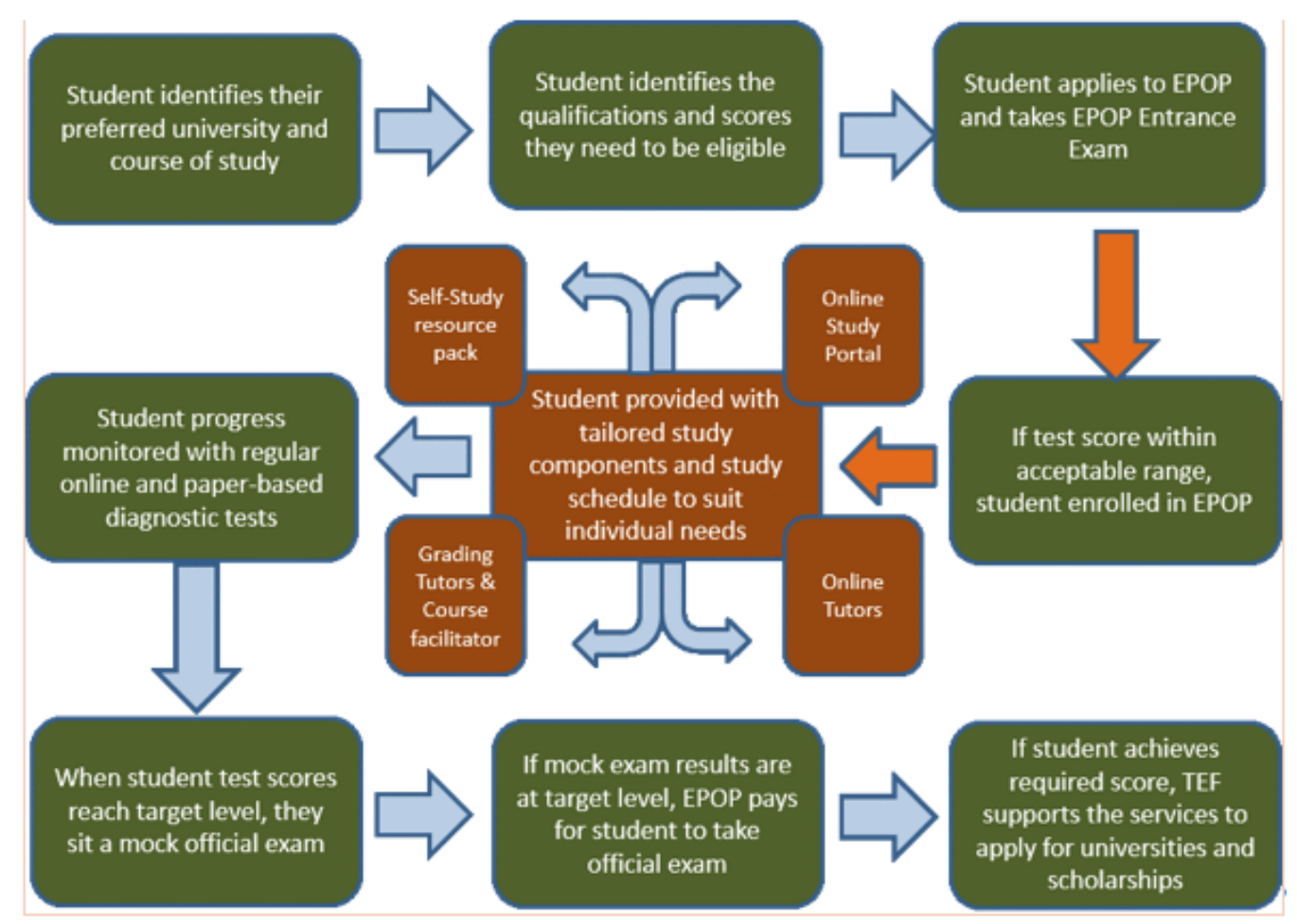

Figure 1. Framework of EPOP

Thabyay Education Foundation (2015)

EPOP also collaborates with learning centers to enroll migrant students. Some learning centers integrate EPOP into their course modules by giving specific class time to study with EPOP within the class schedules. Students can complete courses through online self-study, with the support of an online teacher, or with face-to-face classes at EPOP collaborative partner learning centers. Students are provided a pack of learning materials that includes multiple textbooks, corresponding audio CDs, and a student handbook. The student's progress is monitored with weekly assessments and regular diagnostic tests. When the students' test scores reach the target level, they sit a mock official exam. If the mock exam results are at the target level, EPOP provides the official TOEFL ITP (Institutional Testing Program) testing. When the student achieves the required score, Thabyay Education Foundation provides assistance to apply for universities and scholarships (Thabyay Education Foundation, 2017). Figure (1) summarizes the process in a flowchart.

\section{METHOD}

This study aims to examine the challenges for teachers in implementing the eLearning program in the Myanmar migrant community in Thailand. This study employed a qualitative design (Ary, Jacobs, Sorensen, \& Walker, 2010; Creswell, 2014; Yin, 2017) by using the implementation of the Exam Preparation Outreach Program (EPOP) in Mae Sot, Tak province as a case study. Tak province is located in the northern region of Thailand borders Myanmar. The border town Mae Sot has the highest proportion of migrant students attending learning centers compared to Thailand's other provinces (Harkins, 2019). The research question addressed in this paper is: what are the challenges for teachers of migrant learning centers in the implementation of the eLearning program in the Myanmar migrant community in Mae Sot, Thailand? 


\section{Participants}

The focus of this study is the Myanmar migrant education community in Mae Sot, Thailand. The participants comprised a total of nine educators from nine MLCs in Mae Sot. The purposive sampling (Ary et al., 2010), also known as selective or subjective sampling was used to select the nine MLCs that were already implementing EPOP as part of their higher education program in Mae Sot. The informants for this study were educators who teach and manage the secondary to higher education programs for the Myanmar migrant children in Mae Sot: a teacher, four administrators, and four administrators who also take the teaching role. All nine participants in the study had been living and working in the migrant community for more than five years and had been in their current positions for at least three years.

Table 1. Participants' Characteristics

\begin{tabular}{ll}
\hline Code & Class \\
\hline A01 & Facilitator, Consultant \\
A02 & Advisor \\
A03 & Program Assistant \\
A04 & Director \\
AT01 & Coordinator, Teacher \\
AT02 & Director, Teacher \\
AT03 & Coordinator, Teacher \\
AT04 & Vice-principal, Teacher \\
T01 & Teacher \\
\hline
\end{tabular}

Note. $A=$ Admin, $A T=$ Admin \& Teacher, $T=$ Teacher

The purpose of the research, procedures, and anticipated outcomes were explained to the participants to ensure ethical conduct. Participation in the study was voluntary and participants could withdraw at any time. Participants were assured that all information would be held in the strictest confidence, and that only summary information and quotations (not be attributed to any participant by name) would be used for analysis. Participants were anonymized by using codes shown in Table (1).

\section{Data Collection and Analysis}

The case study exploratory qualitative research approach is applied to investigate the challenges of the migrants' community in implementing EPOP in Mae Sot migrant learning centers. The researcher contacted participants by email and phone to set up interviews in March 2018. The semi-structured in-depth interviews were conducted over the phone call and via online social media applications such as Facebook Messenger, Google Hangouts, and Skype. The researcher recorded the interviews and took notes throughout the interviews.

The recorded interviews were transcribed and coded. All participants were given a number to protect their identities for ethical and security issues. Qualitative data were analyzed using thematic network analysis (TNA). The researchers organized, categorized, and coded the qualitative transcribed textual data. The researcher read and reread the transcripts to establish the basic themes, categorizing them into organizing themes and generating global themes (Attride-stirling, 2001). Detailed descriptions of the themes are shown in Table 2 to uphold the trustworthiness of the analysis. 
Table 2. Thematic Networks Analysis of the Study

Challenges of MLC in implementing EPOP

\begin{tabular}{|c|c|c|}
\hline Themes & Organizing Themes & Basic themes/codes \\
\hline \multirow{5}{*}{ 1. Accessibility } & & Internet access \\
\hline & Infrastructure & Device \\
\hline & Resources & Equipment \\
\hline & Access & Study center \\
\hline & & Access \\
\hline \multirow{6}{*}{ 2. Attitude } & & Objective \\
\hline & & Attrition/dropout \\
\hline & Motivation & Flexibility \\
\hline & Determination & Learning environment \\
\hline & & Self-confidence \\
\hline & & Honesty \\
\hline \multirow{4}{*}{ 3. Networking } & & Recruitment \\
\hline & Continual Communication & Objectives \\
\hline & Collaboration & Follow up \\
\hline & & Information Gap \\
\hline \multirow{4}{*}{ 4. Contents } & \multirow{4}{*}{$\begin{array}{l}\text { Target beneficiaries } \\
\text { Test form needed } \\
\text { Offered courses }\end{array}$} & Target beneficiaries \\
\hline & & Benefits for Prof Dev \\
\hline & & linking to $\mathrm{HE}$ \\
\hline & & Limitations of test format \\
\hline \multirow{3}{*}{ 5. Support services } & \multirow{3}{*}{ Training } & Facilitation \\
\hline & & Orientation \\
\hline & & Technical skills \\
\hline \multirow{2}{*}{ 6. Accreditation } & \multirow{2}{*}{ Affiliating } & Certification \\
\hline & & Recognition \\
\hline
\end{tabular}

\section{Role of the Researcher}

Merriam (2002) stated that the researcher is the primary instrument for data collection and data analysis in all forms of qualitative research. As the qualitative approach is applied in this study, interview protocol is used as a guideline instrument and the researchers served as the key instrument. Qualitative literature suggests that the role of the researcher is important in the process of conducting a study. Researchers are active participants in the data gathering process (Ary et al., 2010; Merriam, 2002).

\section{Validity and Reliability}

The validity and reliability of qualitative research depend on the accuracy and credibility of findings (Seidman, 2006). The term trustworthiness consists of four key criteria: credibility, transferability, dependability, and confirmability (Lincoln and Guba, 1985). Creswell suggests that "validation of findings occurs through the steps in the process of research". Qualitative researchers need to check the findings by using certain procedures for accuracy (Creswell, 2014). In this study, trustworthiness was enhanced by triangulation, member checks, peer review, and research's position or reflexivity. To develop a comprehensive understanding and to obtain information about the subject, researchers cross-checked the collected data through multiple sources which include interview transcripts and document analysis from a variety of sources. To ensure the truth value of the data and to help improve the credibility of the findings, the researchers checked with the information providers throughout the analysis process. Besides, researchers checked with peers through inclass discussions, seminars, and conference presentations. The researchers carefully input the feedback to strengthen the reliability as well internal-external credibility of the findings. 


\section{FINDINGS AND DISCUSSIONS}

The analysis identified six groups of challenges in implementing EPOP in migrant learning centers in Mae Sot: accessibility, attitude, networking, course contents, support services, and accreditation.

\section{Accessibility}

The most common challenge identified throughout the participant responses is the accessibility of the eLearning program in the migrant community. Accessibility in this study implies the infrastructure, resources of the migrant community, and the entry-level to access the EPOP program. All of the participants highlighted the inadequate infrastructure and financial constraints of MLCs and the accessibility of the program as the entry-level is high for the majority of the migrant students. The interviews with the MLC teachers and administrators revealed that EPOP is a very good program for the students who aim higher and who would like to continue their studies in international universities after graduating from migrant learning centers. However, not every student can join EPOP due to the lack of resources such as infrastructure and learning equipment in the migrant community. T01 stated:

Sometimes it is difficult when the students need to download the lessons from the EPOP portal, but the connection is very slow. We hope to see an improvement of ICT infrastructure in MLCs as eLearning can play an important role for migrant students in the future (AT04).

Similarly, AT02 shared that "we also use some e-resources like Khan Academy in our school. But it's really diffcult for the MLCs to invest in eLearning resources. Because they don't have many computers, the computers they do have are very old" (AT02).

AT04 and A01 remarked that several learning centers provide primary and secondary education for the migrant students in the Mae Sot area, but there are not many schools that prepare for higher education. AT04 added that EPOP was essential not only for the students but also for the teachers and full-time employees who would like to improve their English skills. AT03 and A04 gave similar opinions:

I have seen many students are working full-time but want to improve their English, studying with EPOP at the same time. And it is also helpful for the higher education programs and for those who would like to further their studies at the university level. So, the migrant community needs the EPOP program (AO4).

A02 and A04 stated that EPOP used to fully support migrant students in the years of 2009-2010 before the political situation in Myanmar changed and when there were very few programs helping Myanmar migrant students into higher education. A01 expressed a similar opinion: "Since EPOP's main office moved to Myanmar I found that EPOP's attention on the migrant community has been decreased. I learned that there is less support for the migrant students."

In addition to the limitation of resources in the migrant community, the English proficiency entry level of the program is holding back the students from accessing the EPOP program (AT04). According to the educators of MLCs, the EPOP entry level is higher than that of the level of many MLC graduates. T01 and AT02 shared this opinion:

Most of my students wanted to join EPOP after they finished their studies at the MLC, for EPOP is a precious program, they needed to upgrade their English proficiency to reach their aims of getting into the desired international program. However, not many students pass the EPOP entrance exam on their first attempt. Some of them gave up on their education when they have nowhere else to go further (T01).

For my students, they are not at the university level yet, where they are not academic level yet, and they are still doing the lower-level GED yet. I don't think that EPOP meets that situation very well. However, in a school like ACU, I would highly recommend doing EPOP as they are doing universitylevel studies, but their English might not be academic level. So they might need to improve their writing or reading skills, so doing EPOP alongside with an ACU course will be worth it (AT02). 
A01, A02, and A04 suggested for dealing with the needs of the community, EPOP should develop foundation or bridging courses for the students who are not ready to start the academic English courses. A02 and T01 added that more migrant young adults will join EPOP then.

These challenges of accessibility in eLearning are consistent with reported observations in the literature about inadequate infrastructure, financial constraints, and lack of suitable devices (Nyagorme, 2014; Tarus, Gichoya, \& Muumbo, 2015). The shrinking of the supports of international organizations to the migrant community is also found in the studies of the border situations (Loong, 2019; Payaksak, 2019; Purkey \& Irving, 2019; Tyrosvoutis, 2019). The lack of financing makes learning centers largely dependent on external funding for operating the programs and learning resources (Lee \& Kim, 2016). Rezaei (2009) found that the financial situations triggered challenges in developing online learning in higher education institutions in Iran. In a study of ICT barriers and critical success factors in developing countries, scholars (Touray, Salminen, \& Mursu, 2013) found that accessibility of the eLearning opportunities is limited due to the poor infrastructure and learning resources which negatively affects the implementation of eLearning in developing countries. To ensure inclusive education and providing support for migrants and all children, not only the policy, but also eliminating financial obstacles and sustainable investments are needed (Budginaite, Siarova, Sternadel, Mackonyte, \& Spurga, 2016; Purkey \& Irving, 2019; Tomasevski, 2006).

\section{Attitude}

The second-largest challenge described by the participants is the attitude of the students in online learning. Based on the factors and rationale discoursed by the participants, EPOP not only helps the students with their English proficiency but also empowers them, which positively impacts students' self-reliance. However, not knowing their aims is the major issue among the dropouts. Half of the respondents commented that when the students take the next steps, for instance, get into high-level institutions like University of People (UoP) online courses, those who have experienced eLearning like EPOP show more self-confidence than those who have not (T01, A03, A04, AT01, and AT04). AT01 added that EPOP trains them in self-reliance: time management in the self-directed flexible learning environment is a benefit of learning with EPOP in addition to improving English proficiency.

A03 denoted that the successful EPOP learners are those who are intrinsically motivated and know what they want and what they need to do to achieve their goals. They use their learning opportunities well and are very persistent (A03). AT01 said: "You know, it is a very long way for them passing many steps from migrant education to the university education level. EPOP is one important step." T01 described a student from a refugee camp who joined EPOP as soon as she had done the high school final exam, she planned to be able to meet the admission requirements of her desired university and was trying hard to follow her plan. AT01 who completed EPOP last year and is currently facilitating 20 EPOP students, shared his experience studying with EPOP: "Time management is challenging because I am a full-time employee as well. I bring my laptop whenever and wherever I travel."

However, some students joined EPOP with high motivation but became inactive after a short time (AT03). In general, students who just completed their studies at the MLC are motivated to seek any opportunities to continue their studies. They may or may not have a clear idea of what they want to do next. Many students took the entrance exam of any programs they knew of. As a result, the students who did not have a clear aim for doing the EPOP course soon dropped out or cheated on the assigned tasks. Gradually they were left behind (T01, A01, A02, A04, AT03, and AT04).

The educators of MLCs suggested that EPOP should provide clear information regarding the aims and objectives of the EPOP program, clear guidelines of course completion requirements and program standards before the applicants take the EPOP entrance examination.

AT01 said that the writing assessment is the best part of EPOP training. "Cheating often happened. That's too bad. Although EPOP writing tutors strictly check for plagiarism on the written assignments, it is difficult to control the behavior of students over the LMS-based quizzes", AT03 added. AT02 shared:

As a teacher, I like the flexibility so that students can do it when they are free, when it's nighttime, when they are home or when they are traveling. But I see that students do not do the regular study, 
a lot of students do the weekly test, quiz, and review quizzes. So it's a little bit complicated as what I'm seeing as a good point, the flexibility, is ideally a good point, but practically it doesn't work out as it should.

These challenges are similar to those identified by scholars in the field. Holmes and Gardner (2006, pp. 401403) state that having self-discipline, self-motivation, and time management skills are keys for successful online learning as eLearning applies the student-centered approach. Although eLearning LMS allows the learners to work at their own pace, with high satisfaction and low stress, it is difficult to control bad activities like cheating in an online exam environment (Owens, 2015). The challenges of student attitude such as selfdiscipline, lack of motivation, and commitments which found in this study are similar to those conducted in previous students in the field of online learning (Andersson, 2008; Atisabda, Kritpracha, Kaosaiyaporn, \& Pattaro, 2015; Dyrbye, Cumyn, Day, \& Heflin, 2009; Gyamfi \& Sukseemuang, 2018; Konayuma, 2015; Owens, 2015; Tyler-Smith, 2006). According to Bandura (1993), students' learning orientations are influenced by both internal factors such as goals and expectations, and by external environmental factors. Rosenberg (2001) indicates that providing instructional objectives which are meaningful to the learners enhances their motivation to learn.

\section{Networking with MLCs}

Lack of networking with migrant educators was listed as the third most-cited challenge by the participants. A02 shared that the migrant community is not stable as people move back and forth all the time. Therefore, even though one school has been implementing EPOP for several semesters, it is not clear if the teachers of next year in that school will be able to implement EPOP (AT04, T01, A02, and A04). AT02 stated: "EPOP has the potential to be extremely beneficial for the migrant community, but practically it depends on how much effort they (EPOP) put in."

AT01 indicated that "EPOP needs to introduce the program regularly as a new program in the community. You can't think that EPOP is already known by the community. EPOP is new for the new teachers and new administrators". A02 expressed a similar opinion: "In our community, we have the Education Working Group (EWG), Education Working Network (EWN), Migrant Education Coordination Center (MECC), Burmese Migrant Workers' Education Committee (BMWEC), Burmese Migrant Teacher Association (BMTA) with about 700 educators and Parents Teachers Association (PTA). I've never seen EPOP's involvement in any activities." According to the teachers and administrators, EPOP needs to participate in the MLC educators meetings to get information updates from the community, to promote the program, and to stimulate the relationship between the MLC and EPOP. Although many students know about the program and benefits of studying with EPOP, many MLC teachers have no idea how this eLearning platform works and what are the requirements (A01, A02, A04, AT01). A02 added that "therefore, EPOP should have more community involvement and hold presentations regularly in migrant schools"

A01, A02, AT03, and AT04 suggested that EPOP should take the organizations where students are based as the working partner. EPOP should have regular communication about the students' learning activities with their based MLCs to work together for the student's achievement (A02). The challenge of continual communication and collaboration reflects Rogers' suggestion on the observability of the innovations. Visibility is one of the factors which creates communication among the networks and facilitates the adoption of the innovation. A society will only adopt an innovation if it is compatible with existing values and practices (Rogers, 2003). Arkorful and Abidoo (2015) stated that eLearning implementation decreases institutions' socialization role. Asynchronous communication channel such as email is commonly used for collaboration with the users (Rivoltella, 2006). However, the adoption of a new idea depends on characteristics of the innovation, communication channels, time, and the social system of the community (Rogers, 2003). Rosenberg (2001) suggested that technology is a tool to be used, human interaction and collaboration should not be entirely replaced with technology. Collaboration and networking of related personnel are very important (Atisabda et al., 2015) and are also associated with the accessibility of the program, student recruitment, and retention. Rivoltella (2006) conveyed that systematic relationships among individuals and technologies are necessary to its high-impact implementation. The International Council for Open and Distance Education (Ossiannilsson, Williams, Camilleri, \& Brown, 2015) reveals the need for knowledge building, knowledge sharing, capacity building, and coordination among stakeholders. 


\section{Course Contents}

The fourth most-cited challenge indicated by the participants is related to the EPOP course contents, specifically the English proficiency test form for university admission. The majority of interview respondents, 7 out of 9, mentioned that EPOP is limited to applying only the TOEFL ITP scores in university admission (A01, A02, A03, A04, AT03, AT04, and T01). It would be more beneficial for students if EPOP could help them prepare for other test forms such as the TOEFL iBT exam (A01, A02, A03, AT03, AT04, and T01).

Expressing this opinion about the need for preparation for other tests, A03 said that "most of the universities prefer the TOEFL iBT to the paper-based test form". AT03 shared that when his students had to take the other form of TOEFL test in 2017, they could not find information on where and how students can sit the exam, and there was no information or support to find the resources and the test center.

AT02 stressed the prospective of eLearning in the migrant community:

Especially for children, I don't see the big role of eLearning in the future. One thing where I can see the huge potential of eLearning would be people who already left school, people already working, so maybe they don't want to give up their job and their salary to go back to full-time education. In that situation, eLearning becomes a viable option.

The challenges described by the participants are related to the literature to the barriers of implementing eLearning programs and challenges of the community engagement in capacity-building programs. Eidson (2009) found that the completion of an online course is associated with the relevance of course contents to the learners. Ertmer and Ottenbreit-Leftwich (2010) recognize that teachers adopt the use of technologybased knowledge of both their learners and the subject. Teachers select the most appropriate ICT resources as an integral component to meet the required learning goals of their students (Ertmer \& Ottenbreit-Leftwich, 2010). Relatedly Phiri, Hendricks, and Seedat (2012) identify that the engagement of the community in the capacity-building training courses is influenced by the benefits of the course contents to the members of the community (Phiri et al., 2012).

\section{Support Services}

The fifth challenge identified by the participants is the insufficient technical training support services from the program to MLCs. According to migrant educators, introducing the eLearning practice, conducting the online learning management system (LMS) orientation, providing the technical skills and technical support, and education on the utilization of eLearning opportunities are needed in the implementation of EPOP in the migrant community. Providing these support services to the educators in the migrant community would raise their confidence the in eLearning environment (A02, A04, AT01, AT03, AT04, and T01). A teacher noted the need for training on ICT for teaching and learning:

Our teachers including myself need to upgrade our knowledge and skills in using technology in teaching and learning. Only a few teachers have prior experience in ICT Applications. Therefore, facilitating an eLearning program is hard for us. We need to have orientation training on the application of eLearning and its learning management system (T01).

AT01 also commented that to learn about the program, he enrolled himself in EPOP. After taking some courses, he gained more confidence in facilitating the students learning. He added that at the time of the interview, around 20 students of his MLC were preparing for the TOEFL exam through EPOP.

This challenge replicates the other studies that found institutions should conduct the training for instructors to build the technical competency and knowledge of eLearning (Cleveland-innes, Gauvreau, Richardson, Mishra, \& Ostashewski, 2019; Ertmer \& Ottenbreit-Leftwich, 2010; Gillett-Swan, 2017; Rezaei, 2009). The need to enhance the knowledge of teachers in the utilization of technology in teaching and learning in community learning centers is also observed in a study in the Southernmost of Thailand (Atisabda et al., 2015). The lack of professional development for facilitators and teachers leads to failures in operations (Lee \& Kim, 2016). Other scholars (Andersson, 2008; Dyrbye et al., 2009; Mirmoghtadaie et al., 2019; Saint-Marc et al., 2019) found that the challenges in the implementation of eLearning include the clarity of communication and a supportive environment in teaching and learning. A study by Makokha and Mutisya 
(2016) in Kenya reported that not receiving the relevant training is challenging in implementing an online program. Konayuma (2015) found that inadequate support services for the varying levels of experience and knowledge of teachers hindered eLearning implementation. These findings also relate to the investigation of perspectives of refugee students in Germany by Halkic and Arnold (2019) which found that offering online education with accompanying support services alleviates difficulties disadvantaged students face in gaining access to higher education.

\section{Accreditation}

The least stated but a substantial concern of the migrant educators is the need for broader accreditation of the EPOP TOEFL ITP certificate. According to the International Council for Open and Distance Education (ICDE) accreditation is "a process conducted by a national regulatory agency, or similar, empowered with ensuring that institutions comply with the set of defined requirements to operate as a Higher Education Institution and offer defined qualifications and awards" (Ossiannilsson et al., 2015). AT03 and A02 said that currently EPOP's TOEFL ITP scores are recognized by a limited number of universities in Thailand. Three MLC educators shared their enthusiasm that the benefit of implementing EPOP in MLCs could dramatically increase if EPOP gains accreditation from the regional and national educational associations (A02, AT03, and T01). T01 explained the situation and suggested that:

I would also strongly suggest EPOP connect with more universities to recognize the EPOP certificate. At the moment, there are very few universities that recognize the EPOP TOEFL ITP scores. Most of my students studying with EPOP have the aim of successful university admission.

The participants suggested having an agreement with universities and government education ministries in both Thailand and Myanmar for the recognition of the EPOP TOEFL ITP certificate as the accredited certificate.

The International Council for Open and Distance Education (ICDE) revealed that there is not much evidence of the implementation of quality models of online learning programs integrated within the national accreditation system (Ossiannilsson et al., 2015). Accredited certification plays a critical part in the quality assurance of education and training institutes (Demirel, 2016; Pape \& Wicks, 2009). The migrant education partners have been starting to provide recognized, transferrable transcripts and accredited education for the migrant children (Purkey \& Irving, 2019). It is very important to certify that students have access to quality online learning opportunities. Concerning quality assurance and accreditation, the International Association for K-12 Online Learning (iNACOL) addresses the needs for a quality online program comprising the quality course design and quality online teaching. The iNACOL suggests beginning this initiative by assessing the existing online program standards including accreditation standards of the program (Pape \& Wicks, 2009). Demirel (2016) recommended the establishment of programs to provide recognition from related reputable institutions through accreditation, so that the students, the teachers, and thus the community can be confident in the program.

\section{CONCLUSION}

Although the migrant community acknowledges the benefits and opportunities of online learning, MLCs have not yet fully implemented eLearning as a mode of education. There are particular challenges to effectively implement online learning programs in migrant communities. Six types of challenges were identified: accessibility, attitude, networking, course contents, support services, and accreditation. Based on the frequencies of responses, this study claims that lack of accessibility, attitude and networking in the community are the major barriers among the other challenges in the migrant community. The results of this study can be used for the improvement of the current eLearning programs as well as the implementation of new programs for students in similar situations. The results and explanations of this study should be seen within the study limitations. First, it is a single case study of one eLearning provider that is EPOP. Secondly, this study includes only the perspective of the MLCs teachers and administrators. Future studies by including the perspective of the students and service providers can strengthen the challenges found in this study. 
Based on our study, the implementation of eLearning is at its early stage in the Myanmar migrant community in Thailand. MLCs have not yet fully implemented eLearning as a mode of education. Although eLearning cannot replace traditional classroom training, it has a huge potential for meeting a growing demand for higher education for migrant students (Cross, 2004; Rosenberg, 2001). In the case of continuous education for migrant and refugee students, e-Learning can play a significant role (Halkic \& Arnold, 2019). It would be very beneficial for migrant students to have eLearning study centers in the migrant community with proper ICT resources including suitable devices, reliable power supply, and internet access. On the other hand, for the migrant learning centers, the needs for teachers can be reduced and the number of students can be increased by implementing an eLearning platform in the MLC.

To solve these challenges, eLearning providers should consider developing courses for the beginner level, establishing online learning study centers with suitable infrastructure and resources in the community, providing ICT knowledge training, and having regular communication with migrant educators. Government organizations and the private sector should partner to develop and implement an eLearning strategy for migrant children as an alternative pathway to higher education. The lack of appropriate infrastructure in migrant learning centers is one of the greatest challenges hindering the implementation of eLearning programs in marginalized areas.

Especially most of the MLCs are not well equipped and face challenges funding investment into physical infrastructure in school settings. The consequence of the lack of funding (Lee \& Kim, 2016; Loong, 2019; Payaksak, 2019; Purkey \& Irving, 2019; Tyrosvoutis, 2019) leads to the incapability of the centers, a lack of appropriate infrastructure and learning resources (Rezaei, 2009; Touray et al., 2013). Additionally, relying on donor funds alone is not sufficient. Educational ministries need to make contributions and should play an active role in supporting MLCs. For learners who could not afford to pay for regular classes, the students who are living in the refugee camps with restrictions of movement, and those who are working full-time but willing to upgrade their skills, an eLearning platform is great support (Halkic \& Arnold, 2019). Therefore, to earn the full benefits of eLearning, all parties, educational authorities, online learning providers, migrant education providers, and MLCs, should commit time, attention, and careful strategic planning towards eLearning implementation in the migrant community.

Acknowledgments: The authors would like to acknowledge the support of Thailand's Education Hub for ASEAN Countries (TEH-AC) and the Prince of Songkla University in funding this work. Also, we would like to thank all the participants in this study and Thabyay Education Network Foundation.

Authors' Note: A shorter version of this study was presented in the National and International Conference on Education (NICE) in July 2018, Phuket, Thailand; and in the Conference 2020: Progress toward Myanmar's Sustainable Development Goals in January 2020, Yangon, Myanmar.

\section{BIODATA and CONTACT ADDRESSES of AUTHORS}

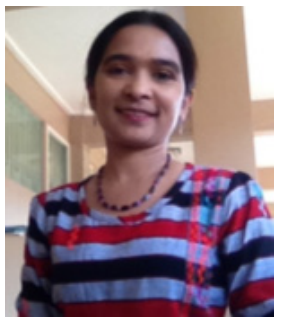

Sandar LWIN is an Ed.D. candidate in Educational Administration at Prince of Songkla University Thailand. Sandar gained her M.Ed. in Curriculum and Instruction at Assumption University of Thailand in 2015. She has been working with communitybased organizations and migrant learning centers which provide access to education for migrant and refugee children in Thailand for more than ten years. Her research interests are online learning, education policies, education for out-of-school children, and education for marginalized groups of children.

\section{Sandar LWIN}

Faculty of Education

Address: Prince of Songkla University, 94000, Mueang Pattani, Thailand

Phone: +66 888933952

Email: sandarln@gmail.com 


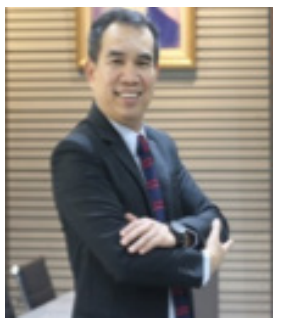

Associate Professor Dr. Ekkarin SUNGTONG received Ph.D. in Educational Leadership and Policy Analysis from College of Education, the University of MissouriColumbia, U.S.A. in 2007. He has been the dean of Faculty of Education, Prince of Songkla University since 2015. He was the former vice-president of Thailand Education Dean Council (TDEC). Currently, he has also served as the committee of Administrator Professional Educational Development Association of Thailand (APEDA). His research interests are education policies, teacher education development, multicultural education and educational leadership. In 2020, he received the Dean's Distinguished Awards for outstanding deanship from Thailand Education Dean Council.

\section{Ekkarin SUNGTONG}

Dean of Faculty of Education

Address: Prince of Songkla University, 94000, Mueang Pattani, Thailand

Phone: +6673313928

Email: ekkarin.s@psu.ac.th

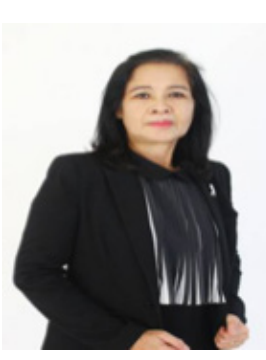

Associate Professor Dr. Virintorn AUKSORNNIT earned doctoral and master's degrees in Rural Development from Central Luzon State University, the Philippines, in 2001 and 1988, respectively. Dr. Auksornit had another master's degree in social development from the National Institute of Development Administration, Thailand. She was an associated dean for System Development and Academic Services Affairs of Faculty of Education. Currently, Dr. Auksornit serves as a secretariat of the Center of Professional Development for Teacher and Educational Personnel in Southern Thailand. Her research interests include public sector management, quality management, local development, and professional development

\section{Virintorn AUKSORNNIT}

Faculty of Education

Address: Prince of Songkla University, 94000, Mueang Pattani, Thailand

Email: virintorn5799@gmail.com

\section{REFERENCES}

Adjabeng, S. (2017). The status and challenges of online distance education programs in post-secondary institutions in Ghana. University of North Texas.

Alienor Salmon, Thanwai, S. A., \& Wongsaengpaiboon, H. (2013). In School, in Society: Early childhood development in Myanmar migrant communities in Thailand. In VSO Thailand. Bangkok: VSO Thailand.

Andersson, A. (2008). Seven major challenges for e-learning in developing countries: Case study eBIT, Sri Lanka. International Journal of Education and Development Using Information and Communication Technology, 4(3), 45-62.

Arkorful, V., \& Abaidoo, N. (2015). The role of e-learning, advantages and disadvantages of its adoption in higher education. International Journal of Instructional Technology and Distance Learning, 12(1), 29-42. https://doi.org/10.3991/ijac.v3i2.1322

Arphattananon, T. (2012). Education that leads to nowhere: Thailand's education policy for children of migrants. International Journal of Multicultural Education, 14(1), 1-15.

Ary, D., Jacobs, L. C., Sorensen, C. K., \& Walker, D. A. (2010). Introduction to Research in Education.

Atisabda, W., Kritpracha, C., Kaosaiyaporn, O., \& Pattaro, A. (2015). Strategies for Distance Learning to Increase Academic Achievement of High School Students in Risk Area of the Southernmost of Thailand. Procedia - Social and Behavioral Sciences, 174, 2384-2389. https://doi.org/10.1016/j. sbspro.2015.01.905 
Attride-stirling, J. (2001). Thematic networks: an analytic tool for qualitative research Jennifer. Qualitative Research.

Australian Catholic University. (2009). ACU refugee program on the Thai-Burma border. Retrieved from https://www.acu.edu.au/giving-to-acu/what-you-can-support/acu-refugee-program-on-the-thaiburma-border

Bandura, A. (1993). Perceived Self-Efficacy in Cognitive Development and Functioning. Educational Psychologist, Vol. 28, pp. 117-148. https://doi.org/10.1207/s15326985ep2802_3

Budginaite, I., Siarova, H., Sternadel, D., Mackonyte, G., \& Spurga, S. A. (2016). Policies and practices for more equality and inclusion in and through education:

Evidence and policy guidance. Luxembourg: Office of the European Union.

Chamratrithirong, A., \& Punpuing, S. (2017). The "Regional Demographic Transition " towards Peace and Prosperity : A Case Study of Thailand and its Neighboring Countries.

Chongkittavorn, K. (2012, October 7). Educating the next generation of Myanmarese children. The Nation Thailand. Retrieved from https://www.nationthailand.com/opinion/30191853

Cleveland-innes, M., Gauvreau, S., Richardson, G., Mishra, S., \& Ostashewski, N. (2019). Technologyenabled learning and the benefits and challenges of using the community of inquiry theoretical framework. International Journal of E-Learning \& Distance Education, 34(1), 1-18.

Creswell, J. W. (2014). Research design: qualitative, quantitative, and mixed method (4th ed.). California: SAGE Publications.

Cross, J. (2004). The future of eLearning. On the Horizon, 12(4), 151-157. https://doi. org/10.1108/10748120410564458

Demirel, E. (2016). Accreditation of Distance Learning. Universal Journal of Educational Research, 4(10), 2457-2464. https://doi.org/10.13189/ujer.2016.041026

Dowding, L. (2014). Pathways to a Better Future : A Review of Education for Migrant Children in Thailand - A Situational Analysis of Two Communities: Bangkok and Mae Sot. In Save the Children, World Education.

Dyrbye, L., Cumyn, A., Day, H., \& Heflin, M. (2009). A qualitative study of physicians' experiences with online learning in a master's degree program: Benefits, challenges, and proposed solutions. Medical Teacher, 31(2), e40-e46. https://doi.org/10.1080/01421590802366129

Eidson, L. A. K. (2009). Barriers to E-Learning job training: government employee experiences in an online wilderness management course. University of Montana.

Ertmer, P. A., \& Ottenbreit-Leftwich, A. T. (2010). Teacher technology change: How knowledge, confidence, beliefs, and culture intersect. Journal of Research on Technology in Education, 42(3), 255-284. https://doi.org/10.1080/15391523.2010.10782551

Gillett-Swan, J. (2017). The Challenges of Online Learning: Supporting and Engaging the Isolated Learner. Journal of Learning Design, 10(1), 20-30.

Global Education Monitoring Report. (2019). Migration, displacement and education: building bridges, not walls. In UNESCO. Paris. https://doi.org/10.1017/CBO9781107415324.004

Gyamfi, G., \& Sukseemuang, P. (2018). EFL learners' satisfaction with the online learning program, Tell Me More. Turkish Online Journal of Distance Education, 19(1), 183-202. https://doi.org/10.17718/ tojde. 382798

Halkic, B., \& Arnold, P. (2019). Refugees and online education: student perspectives on need and support in the context of (online) higher education. Learning, Media and Technology, 44(3), 345-364. https://doi.org/10.1080/17439884.2019.1640739

Harkins, B. (Ed.). (2019). Thailand migration report 2019. Bangkok: United Nations Thematic Working Group on Migration in Thailand. Retrieved from United Nations 
Thematic Working Group on Migration in Thailand website: https://thailand.iom.int/Thailand-migrationreport-2019-0

Help Without Frontiers. (2018). A step forward towards the accreditation of migrant education.

Hennebury, L. E. (2007). Transfer of training: E-learning in a global Fortune 500 company.

Holmes, B., \& Gardner, J. (2006). e-Learning: Concepts and Practice. London: SAGE Publications.

International Labour Organization. (2017). TRIANGLE in ASEAN Quarterly Briefing Note: Thailand (January - March 2017).

Itthipongmaetee, C. (2018, August 2). Denied education, Thailand's migrants and refugees go digital. Khao Sod English. Retrieved from https://www.khaosodenglish.com/featured/2018/08/02/deniededucation-thailands-migrants-and-refugees-go-digital/

Jury, A., Sherer, E., David, E.-G., \& Morganti, M. (2016). Learning Zone: facilitating language learning of adult migrants in the host country (A. Jury, Ed.).

Konayuma, G. (2015). A study of the enablers and challenges in the implementation of e-learning policies in technical education, vocational and entrepreneurship training colleges in Zambia (University of Cape Town). University ofCape Town. Retrieved from https://open.uct.ac.za/handle/11427/20063

Lee, R., \& Kim, J. (2016). Community-Based Lifelong Learning and Adult Education: Situations of Community Learning Centres in 7 Asian Countries. In T. Krausz (Ed.), United Nations Educational, Scientific and Cultural Organization (Vol. 37).

Lincoln, Y. S., \& Guba, E. G. (1985). Naturalistic Inquiry. Thousand Oaks, CA: SAGE Publications.

Loong, S. (2019). The neoliberal borderscape: Neoliberalism's effects on the social worlds of migrants along the Thai-Myanmar border. Political Geography, 74. https://doi.org/10.1016/j.polgeo.2019.102035

MacLaren, D. (2013). Tertiary Education For Refugees: ACU's Program On The Thai-Burma Border. All Ireland Journal of Higher Education, 5(3), 1491-1494.

Makokha, G. L., \& Mutisya, D. N. (2016). Status of E-Learning in Public Universities in Kenya. International Review of Research in Open and Distributed Learning, 17(3). Retrieved from https://files.eric. ed.gov/fulltext/EJ1102715.pdf

Mirmoghtadaie, Z., Ahmady, S., Kohan, N., \& Rakhshani, Z. (2019). Explaining the Concept and Dimensions of Professional Functions in Online Learning System of

Medical Sciences: A Qualitative Content Analysis. Turkish Online Journal of Distance Education, 20(4), 61-72. https://doi.org/10.17718/tojde.640510

Mohebi, S., Parham, M., Sharifirad, G., \& Gharlipour, Z. (2018). Social Support and Self - Care Behavior Study. Journal of Education and Health Promotion, 7, 1-6. https://doi.org/10.4103/jehp. jehp_39_18

Nawarat, N. (2012). Thailand Education Policy for Migrant Children from Burma. Procedia - Social and Behavioral Sciences, 47, 956-961. Retrieved from http://www.sciencedirect.com/science/article/ pii/S1877042812024998

Nawarat, N. (2018). Education obstacles and family separation for children of migrant workers in Thailand: a case from Chiang Mai. Asia Pacific Journal of

Education, 38(4), 488-500. https://doi.org/10.1080/02188791.2018.1530191

Nyagorme, P. (2014). E-learning adoption and utilization: a comparative study of Kenyatta University, Kenya and University of Cape Coast, Ghana. Kenyatta University.

Ossiannilsson, E., Williams, K., Camilleri, A. F., \& Brown, M. (2015). Quality Models in Online and Open Education around the Globe: State of the Art and Recommendations. Oslo: International Council for Open and Distance Education - ICDE. Retrieved from http://elib.tcd.ie/login?url=http:// search.ebscohost.com/login.aspx?direct=true $\& \mathrm{db}=$ eric $\& A N=E D 557055 \&$ site=eds-live 
Owens, H. S. (2015). Cheating within online assessments: A comparison of cheating behaviors in proctored and unproctored environments. Mississippi State University.

Pape, L., \& Wicks, M. (2009). National Standards for Quality Online Programs. International Association for K-12 Online Learning, 1-34. Retrieved from http://www.eric.ed.gov/ERICWebPortal/ recordDetail?accno=ED509638

Payaksak, K. (2019). Monitoring and evaluation report on NFPE and NFME education management of Myanmar in the area of Mae Sot, Tak province supporting by Help without Frontiers. Retrieved from https://helpwithoutfrontiers.org/sites/helpwithoutfrontiers.org/files/resources-docs/nfpe_ evaluation_report_2019_eng.pdf

Petchot, K. (2014). The Right to Education for Migrant Children in Thailand: Liminal Legality and the Educational Experience of Migrant Children in Samut Sakhon. In T.-D. Truong, D. Gasper, J. Handmaker, \& S. I. Bergh (Eds.), Migration, Gender and Social Justice: Perspectives on Human Insecurity (Vol. 9, pp. 307-323). Berlin: Heidelberg. https://doi.org/10.1007/978-3-642-280122_17

Phiri, L. L., Hendricks, N., \& Seedat, M. (2012). Community centered learning: a pathway to community engagement. Journal of Psychology in Africa, 22(4), 577-580. https://doi.org/10.1080/1433023 7.2012.10820571

Purkey, M., \& Irving, M. (2019). The importance of access and accreditation: learning from the ThailandMyanmar border. In M. Couldrey \& J. Peebles (Eds.), Education: needs, rights and access in displacement (pp. 68-71). Refugee Studies Centre.

Rezaei, M. (2009). Challenges of developing online learning in higher education in Iran. Turkish Online Journal of Distance Education, 10(4), 80-90. https://doi.org/10.17718/tojde.50940

Rivoltella, P. C. (2006). Education and Organization: ICT, Assets, and Values. In A. Cartelli (Ed.), Teaching in the knowledge society: new skills and instruments for teachers (pp. 54-63). Hershey: Information Science Publishing.

Rogers, E. M. (2003). Diffusion of innovations (fifth). New York, NY: FREE PRESS.

Rosenberg, M. J. (2001). E-learning : Strategies for Delivering Knowledge in the Digital Age. New York: McGraw-Hill Professional.

Saint-Marc, P., Ratiney, R., \& Schlatter, J. (2019). Challenges in implementing an E-Learning education program for syringe pump use. International Journal of Nursing Education Scholarship, 16(1), 1-10. https://doi.org/10.1515/ijnes-2017-0079

Save the Children, \& World Education. (2014). Pathways to a better future: a review of education for migrant children in Thailand - Policy brief. In Save the Children.

Seidman, I. (2006). Interviewing as Qualitative Research: A Guide for Researchers in Education and the Social Sciences (3td ed., Vol. 37). New York: Teachers College Press

Tarus, J. K., Gichoya, D., \& Muumbo, A. (2015). Challenges of implementing E-learning in Kenya: A case of Kenyan public universities. International Review of Research in Open and Distance Learning, 16(1), 120-141. https://doi.org/10.19173/irrodl.v16i1.1816

Thabyay Education Foundation. (2017). Annual Report 2016-17.

Thet, M. M., \& Pholphirul, P. (2016). The Perception of Myanmar Development on its Return Migrants: Implications for Burmese Migrants in Thailand. Journal of International Migration and Integration, 17(4), 995-1014. https://doi.org/10.1007/s12134-015-0446-9

Tomasevski, K. (2006). The State of the Right to Education Worldwide Free or Fee: Executive Summary. World Bank, 1-21.

Touray, A., Salminen, A., \& Mursu, A. (2013). ICT barriers and critical success factors in developing countries. The Electronic Journal of Information Systems in Developing Countries, 56(7), 1-17. https://doi.org/10.1002/j.1681-4835.2013.tb00401.x 
Tyler-Smith, K. (2006). Early attrition among first time eLearners: A review of factors that contribute to dropout, withdrawal and non-completion rates of adult learners undertaking eLearning programmes. Journal of Online Learning and Teaching, 2(2), 73-85.

Tyrosvoutis, G. (2019). Bridges: Participatory action research on the future of migrant education in Thailand. In G. Tyrosvoutis (Ed.), TeacherFOCUS Myanmar.

UNESCO- News. (2015). The 2nd Consultation Meeting on Education for Myanmar and Thailand Children. Retrieved August 10, 2019, from UNESCO Bangkok website: https://bangkok.unesco. org/content/2nd-consultation-meeting-education-myanmar-and-thailand-children

Yin, R. k. (2017). Designing Case Studies. In Case Study Research and Applications: Design and Methods (6th ed.). California: SAGE Publications. 